\title{
Ariane set to go in two weeks, Columbus in the balance
}

\section{Paris}

EUROPE's chances of a significant involvement in space in the next century could be radically affected by events in the next few months. As scientists at Kourou, the European Space Agency (ESA) launch site in French Guiana, start countdown rehearsal for the Ariane 3 rocket, following an 18month delay, ESA officials are shuttling between Paris and Washington in an effort to complete negotiations with the US National Aeronautics and Space Administration (NASA) on Europe's Columbus contribution to the US space station.

A successful Ariane launch, set for 15 September, is imperative, both for ESA and for Arianespace, its French-based commercial arm. Recent demonstrations of Eastern interest in the commercial space market, with the Soviet Proton and Chinese Long March rocket launches (see Nature 328, 370; 1987 and 328, 659; 1987), have caused nail-biting among already tense European space scientists. Arianespace has a full order book, but it needs to carry out 8 or 9 launches a year until 1990 to make up for lost time. A turbo-pump failure in Ariane's third-stage rocket motor has interrupted Arianespace's lead in commercial satellite launches since March 1986; a new motor had to be designed and tested.

The two telecommunications satellites, ECS4 and AUSSAT K3, due to be put into geostationary orbit by Ariane 3, have now been delivered to Kourou. The European satellite ECS4 will be used for international telephone, business and television communications, while AUSSAT K3 will provide a reliable voice and data link for Australian air-traffic controllers and will beam Australian television throughout the south west Pacific.

Meanwhile, the terms of an agreement allowing ESA to contribute a man-tended free-flying laboratory (MTFL) and a permanently attached pressurized laboratory module to NASA's planned space station have still not been settled. Earlier this year (see Nature 327, 180; 1987), the US Department of Defense upset negotiations when it insisted upon an option to use the space station for military research, a function specifically proscribed by ESA's constitution. Thanks to a standard diplomatic sleight of hand, whereby the crucial military use clause was relegated to an auxiliary agreement, a draft memorandum of understanding between NASA and ESA has been drawn up and, according to a Washington spokesman for ESA, "military use of the platform is not an issue in our discussions with NASA".

Approval of the memorandum must take place in time for the ministerial coun- cil meeting of ESA on 8 and 9 November, when member states will be asked to commit themselves, both legally and financially, to the Columbus programme (comprising MTFL, Hermes and the pressurized module, as well as the British polar orbiting platform). "We are currently in the preparatory phase of the Columbus programme", said an ESA spokesman in Paris, "but we have to enter the development phase, and this will mean commitment and money for 10-20 years. The ministers have to decide yes or no, or yes with amendments."

It was said to be "quite likely" that member states will be asked to increase their contributions to the ESA budget at the November meeting. For this reason, Britain's stop-go attitude to its involvement with the space programme has caused some concern at ESA. "We are following developments with great attention", said the ESA spokesman, "because Britain is an important member country and we would like the British to continue their efforts in space."

France is particularly keen to see a positive outcome at the November meetings but would favour maintaining the Columbus programme even without collaboration with NASA.

The coherence of the programme as a potentially autonomous unit will be the subject of an ESA Task Force report due in mid-September. The MTFL would be serviced at 6-monthly intervals by the (largely French) Hermes shuttle, and both would be launched from Ariane 5 rockets. Go-ahead for Hermes and Ariane 5 will also provide a boost to the economy of Guiana, a French territory, where a Hermes landing strip, a third rocket launch complex and Ariane 5 engine test facilities are planned.

Peter Coles

\section{Storm in space-based teacup over Soviet rocket}

\section{London}

PART of the British press has been occupied during the summer with the theme of Soviet 'industrial domination of space' and an inconclusive argument about the intended function of the new Soviet launching rocket Energiya. Soviet students of the British press may well think this excitement is a response to disappointments about government support for the British National Space Centre.

Three long articles in The Times, describing Soviet plans for space, referred in particular to the well-worn theme of how orbital power stations could collect solar radiation and relay it to the surface of the Earth so as to light Soviet cities and for other purposes.

This conclusion seems to have been taken sufficiently seriously by the Astronomer Royal, Sir Graham Smith, and Sir Bernard Lovell, to have provoked a warning of the hazards of such satellites. In a letter to The Times on 20 August, the radioastronomers say that the development of the Energiya launcher should be seen in military rather than civilian terms.

They also say that plans for collecting solar radiation are uneconomic by a factor of 100 and would be hazardous both because misalignment of the mirrors could harm people living near the ground receivers and by the atmospheric pollution arising from the need to launch one Energiya rocket every day. They add that solar-energy collectors driving infrared lasers could be directed at distant populations simply by steering the collecting mirrors, and call for international negotiation in the context of the Treaty on the Peaceful Uses of Outer Space.

Lovell has long been an opponent of energy-collecting satellites, usually on the grounds that the microwave radiation suggested in earlier US schemes as a means of transferring solar energy to the Earth would interfere with radioastronomy.

A riposte from Mr Gerry Webb, managing director of the London-based consulting company Commercial Space Technologies, which claims to have provided much of the data on which the original articles in The Times were based, says that it is the "height of naivety" to interpret everything the Soviet Union does in space in military terms, that space power is "cheap, clean and limitless", that the "huge" capital costs that daunt Western planners are "more acceptable to the Soviet planning bureaux" and that this technology could "save the world" from "what every expert who has examined future trends" has concluded will be "inevitable industrial and economic collapse".

Neither side in this argument seems to have taken account of what is known of Soviet plans for the exploitation of space. The name of the new Soviet rocket, Energiya, is more probably a reference to its lifting power than to the functions of its payloads. Although there have have been references, as for example by Academician Vladimir Kotel'nikov, to the use of solar collectors a kilometre across, these probably indicate schemes for providing power to space stations and other structures in orbit.

Vera Rich 